\title{
PUBLIC MANAGERS' PERCEPTION OF THE PERFORMANCE MEASUREMENT SYSTEM, WITH EMPHASIS ON THE PERFORMANCE PRISM
}

\author{
Recebido em: 09/07/2020 \\ Aprovado em: 18/09/2020 \\ Otávio Henrique Cintra Monteiro \\ Secretaria de Controladoria do Estado de Pernambuco \\ Brasil \\ ORCID: 0000-0002-7718-7649 \\ E-mail: otavio.cintra.cge@gmal.com
}

\begin{abstract}
Performance measurement system is an instrument that supports better organizational performance. This theme has evolved over time, while systems have become multidimensional and intent on projecting the future. In addition, in an open system logic, the understanding of the stakeholders becomes relevant to a performance measurement system. For this reason, the system model called Prism de Performance draws attention because it is based on stakeholders. Therefore, this article aims to analyze the perception of public managers who work in the implementation of strategic planning and performance on performance measurement systems, with an emphasis on the Performance Prism. Through a questionnaire data were obtained and analyzed using the Kruskal-Wallis statistical model. As a result, it was found that the focus on stakeholders is considered important for a dimension of a performance measurement system and that the Performance Prism is not known by professionals who work with the implementation of strategic planning and monitoring of results, even though the model is applicable to non-profit entities.
\end{abstract}

Keywords: Performance measurement system. Dimensions of performance measurement system. Performance prism and stakeholders. 


\section{INTRODUCTION}

Performance measurement systems are positioned as instruments for providing information to help the organization's success (Brewer \& Speh, 2000). For Kennerley and Neely (2002), although there is already recognition that performance measurement assumes an important role in determining rules established in the management of efficiency and effectiveness, it remains a critical issue for much debate.

Callado and Oliveira (2016) point out that despite several improvements regarding the performance measurement method, the process of selecting relevant metrics has still been a source of potential problem.

Performance measurement continues to present challenges to operational managers and operational management researchers. Operational metrics are poorly understood and guidelines for their use are often poorly articulated (Melnyk et. al., 2004). Performance evaluation is a systematic and continuous process of monitoring the degree to which the objectives and the execution of the agreed goals are achieved, promoting institutional learning and stimulating reflection about what has been done (Callado \& Callado, 2018).

In view of the new demands for improving management, Neely et al. (2001) point out that the "New Economy" requires a new generation of performance measurement structures that take into account aspects related to the business environment. In this scenario, the Performance Prism appears.

Although for Frederico and Cavenaghi (2009) the Performance Prism is not yet a model of performance measurement system widely used worldwide, the authors conclude that it can contribute significantly to organizations. Therefore, in view of the search for changes that in performance management, considering as a factor of organizational sustainability meeting the needs of stakeholders in the organization.

Even though it is not widely used, reinforced by the understanding of Salem et al. (2012), when highlighting that there is little empirical evidence on the practical use of the Performance Prism, according to Sorooshian et al. (2016), the Performance Prism ranks as one of the ten most popular performance measurement systems ever created.

According to Ferreira and Callado (2017), in the context of public organizations, performance measuremet is administrative tool that establishes, in addition to the obligation to point out its administrative and institutional peculiarities, the care to consider further characteristics of the nature of the service provided. This paper aims to analyze the perception of public managers who work in the implementation of strategic planning and performance measurement on performance measurement systems, with emphasis on the Performance Prism.

\section{LITERATURE REVIEW}

The literature review was divided into three parts. The first part deals in a general way with the performance measurement system. The second part draws a comparison between eight main models of performance measurement systems, according to Garengo, Biazzo and Bititci (2005). Finally, the last part addresses the Performance Prism in a specific way. 


\subsection{Performance Measurement System}

According to Cunha and Corrêa (2013), although there has been a significant advance in studies on performance measurement, few definitions have been made until the 1990s and recent studies demonstrate that the theme is still emerging. Thus, the challenges posed by performance measurement still remain (Neely, 2005).

Nascimento et al. (2010) state that there are several views on what would be a valid concept on a performance measurement system. Bititci et al. (1997) affirm the measurement system or performance measurement can be seen as an information system with focus on the performance management of the organization. The performance measurement system is the input for performance management (Striteska \& Spickova, 2012). Therefore, performance measurement is the basis for an assessment of how the organization progresses (Amaratunga \& Baldry, 2002).

Saunila and Ukko (2010) have the same understanding as Keely et al. (1995) who define the performance measurement system as a process of quantifying the efficiency and effectiveness of actions. Lardenoije et al. (2005) expands the definition of the performance measurement system as the use of the list of metrics to quantify the efficiency and effectiveness of actions in a context of linking to strategy and continuous improvement. According to Ahmad et al. (2016), for the quantification of organizational performance to occur, the performance measurement system must use metrics or indicators that capture evidence that make it possible to compare whether the efforts to carry out the planned actions produced the desired results. Klann and Beuren (2014) demonstrate studies that affirm a positive correlation between managerial performance and the perception of managers regarding the increase in organizational results coming from their efforts. Thus, performance management should seek to affect people's behavior in order to generate improvements (Saunila \& Ukko, 2010).

Nudurupati et al. (2011) reinforce that continuous improvement involves a positive behavior of people. Thus, performance measurement mechanisms must address not only financial aspects of the organization. There should be monitoring of the actions more broadly (the entire organization) and with the predictive capacity so that there is an alignment between the organization's vision and the employees' behavior for improvement.

Thus, there was an evolution in performance measurement systems. According to Leite et al. (2011), performance measurement became multidimensional with non-financial measures, integrated and derived from the organizational strategy. In addition, for Bourne et al. (2000), in order to make it possible to project the future the performance measurement system must, in addition to obtaining data internal to the organization, to capture external data that affects its performance.

In a logic in which the organization operates in an open system environment, Angerhofer and Angelides (2006) understand that the stakeholders are a key factor for improving organizational performance. Therefore, a performance measurement system must be built with the parameters of its constitution as existing stakeholders. Therefore, it is essential to understand the relationship between them.

Sorooshian et al. (2016) state that a performance measurement system can be defined as a means of assessing the quality of management in organizations and the value delivered to stakeholders. Likewise, Striteska and Spickova (2012) point out that performance is related to the reach of stakeholders. Success depends on meeting the needs of all stakeholders in the organization. Thus, it is necessary to evaluate organizational performance through internal and external perspectives. 


\subsection{Performance Measurement System Models}

Garengo, Biazzo and Bititci (2005) carried out a survey of eight models of performance measurement systems, considered by the authors as the main models.

Table 1

Eight Performance Measurement System Models

\begin{tabular}{|c|c|c|}
\hline Model & Author & Description \\
\hline $\begin{array}{l}\text { Performance } \\
\text { Measurement Matrix }\end{array}$ & $\begin{array}{l}\text { (Keegan, Eiler and Jones, } \\
\text { 1989) }\end{array}$ & $\begin{array}{l}\text { Helps the company to define its strategic objectives } \\
\text { and translates those objectives into performance } \\
\text { measures. }\end{array}$ \\
\hline $\begin{array}{l}\text { Performance Pyramid } \\
\text { System }\end{array}$ & (Lynch and Cross, 1991) & $\begin{array}{l}\text { Pyramid built on four levels that shows the links } \\
\text { between the organizational strategy and the } \\
\text { operational objectives. }\end{array}$ \\
\hline $\begin{array}{l}\text { Performance } \\
\text { Measurement System for } \\
\text { Service } \\
\text { Industries }\end{array}$ & $\begin{array}{l}\text { (Filtzgerald, Johnstn and } \\
\text { Brignall, 1991) }\end{array}$ & $\begin{array}{l}\text { Focus on six dimensions that seek to link } \\
\text { performance evaluation systems with strategy and } \\
\text { competitiveness. }\end{array}$ \\
\hline Balanced Scorecard & $\begin{array}{l}\text { (Kaplan and Norton, 1992, } \\
\text { 1996) }\end{array}$ & $\begin{array}{l}\text { It is based on four perspectives (financial, } \\
\text { customers, internal processes and learning and } \\
\text { growth). Its main focus is to link strategy to } \\
\text { operational activities. }\end{array}$ \\
\hline $\begin{array}{l}\text { Integrated Performance } \\
\text { Measurement System }\end{array}$ & $\begin{array}{l}\text { (Bititci, Carrie and } \\
\text { MacDevitt, 1997) }\end{array}$ & $\begin{array}{l}\text { It presents two main aspects of performance } \\
\text { measurement: integration of the different business } \\
\text { areas and the implementation of policies and } \\
\text { strategies. It is based on four levels: corporate; } \\
\text { business units; activities; and processes. }\end{array}$ \\
\hline Performance Prism & $\begin{array}{l}\text { (Neely, Adams and } \\
\text { Kennerley, 2002) }\end{array}$ & $\begin{array}{l}\text { It aims to measure the performance of the entire } \\
\text { company. Each face of the prism model } \\
\text { corresponds to an area of analysis: stakeholder } \\
\text { satisfaction; strategies; the processes; capabilities; } \\
\text { and stakeholder contribution. }\end{array}$ \\
\hline $\begin{array}{l}\text { Organizational } \\
\text { Performance } \\
\text { Measurement (OPM) }\end{array}$ & $\begin{array}{l}\text { (Chennell, Dransfield, } \\
\text { Field et al., 2000) }\end{array}$ & $\begin{array}{l}\text { Focus on Small and Medium Enterprises and is } \\
\text { based on three principles: strategic alignment; Law } \\
\text { Suit; and involvement of all organizational levels. }\end{array}$ \\
\hline $\begin{array}{l}\text { Integrated Performance } \\
\text { Measurement for Small } \\
\text { Firms }\end{array}$ & (Laitinen, 1996, 2002) & $\begin{array}{l}\text { Focus on Small and Medium Enterprises. It is based } \\
\text { on seven dimensions, two internal (financial and } \\
\text { competitiveness) and five external (costs, factors of } \\
\text { production, activities, products and revenues). }\end{array}$ \\
\hline
\end{tabular}

Source: Garengo, Biazzo e Bititci (2005), Nascimento et al. (2010) and Bortoluzzi et al. (2010)

Garengo, Biazzo and Bititci (2005) related definitions on the main dimensions that characterize contemporary performance measurement system models, aiming to compare the main models of systems listed by the authors. 
Table 1

Performance Measurement Systems Dimension Definitions

\begin{tabular}{|l|l|}
\hline \multicolumn{1}{|c|}{$\begin{array}{c}\text { Dimensions of Performance } \\
\text { Measurement System }\end{array}$} & \multicolumn{1}{|c|}{ Description } \\
\hline Strategic Alignment & $\begin{array}{l}\text { Strategy is the fundamental dimension of the model. The Performance } \\
\text { Assessment system must ensure that the measures adopted are consistent } \\
\text { with the strategy. }\end{array}$ \\
\hline Strategy Development & $\begin{array}{l}\text { Performance Evaluation helps to develop pre-defined objectives and } \\
\text { strategies. }\end{array}$ \\
\hline Focus on Stakehoders & Performance appraisal systems must cater to different interest groups. \\
\hline Financial and Non Financial Measures & $\begin{array}{l}\text { Performance appraisal systems must make use of financial and non- } \\
\text { financial measures. }\end{array}$ \\
\hline Dynamic adaptability & $\begin{array}{l}\text { Performance appraisal systems must react quickly to changes in internal } \\
\text { and external contexts. }\end{array}$ \\
\hline Process Oriented & $\begin{array}{l}\text { The organization is not seen as a hierarchical structure, but as a } \\
\text { coordinated set of processes. }\end{array}$ \\
\hline Depth / Detailing & $\begin{array}{l}\text { Performance measures are developed in depth and cover all } \\
\text { organizational areas in detail. }\end{array}$ \\
\hline Coverage & The entire organization is subject to evaluation. \\
\hline Cause and effect relationship & $\begin{array}{l}\text { Check if there is a relationship between strategic and operational } \\
\text { objectives. }\end{array}$ \\
\hline Clarity and simplicity & $\begin{array}{l}\text { When setting objectives and performance measures, the methodology } \\
\text { must be simple and clear to communicate to all involved. }\end{array}$ \\
\hline
\end{tabular}

Source: Garengo, Biazzo and Bititci (2005) and Bortoluzzi et al. (2010)

Garengo, Biazzo and Bititci (2005) compared the models according to the dimensions listed in table 2. Therefore, the model that obtains the greatest amount of care can be considered the most complete to meet the needs of organizations.

Table 2

Comparison of Four Models of Performance Measurement Systems

\begin{tabular}{|c|c|c|c|c|}
\hline $\begin{array}{l}\text { Dimensions of Performance } \\
\text { Measurement System }\end{array}$ & $\begin{array}{c}\text { Performance } \\
\text { Measurement } \\
\text { Matrix }\end{array}$ & $\begin{array}{c}\text { Performance } \\
\text { Pyramid System }\end{array}$ & $\begin{array}{c}\text { Performance } \\
\text { Measurement } \\
\text { System for Service } \\
\text { Industries }\end{array}$ & $\begin{array}{l}\text { Balanced } \\
\text { Scorecard }\end{array}$ \\
\hline Strategic Alignment & $\bullet$ & - & $\bullet$ & $\bullet$ \\
\hline Strategy Development & & ○ & • & $\bullet$ \\
\hline \multicolumn{5}{|l|}{ Focus on Stakehoders } \\
\hline Financial and Non Financial Measures & $\bullet$ & $\bullet$ & $\bullet$ & $\bullet$ \\
\hline Dynamic adaptability & & & • & \\
\hline Process Oriented & & $\mathrm{O}$ & & $\mathrm{O}$ \\
\hline Depth / Detailing & - & • & • & $\bullet$ \\
\hline Coverage & & $\bullet$ & $\bullet$ & $\bullet$ \\
\hline Cause and effect relationship & & $\bullet$ & $\bullet$ & $\bullet$ \\
\hline Clarity and simplicity & $\bullet$ & & & \\
\hline
\end{tabular}

- Meet completely o Meet partialy

Source: Garengo, Biazzo and Bititci (2005) and Bortoluzzi et al. (2010) 
Table 3

Comparison of Four More Models of Performance Measurement Systems

\begin{tabular}{|l|c|c|c|c|}
\hline \multicolumn{1}{|c|}{$\begin{array}{c}\text { Dimensions of Performance } \\
\text { Measurement System }\end{array}$} & $\begin{array}{c}\text { Integrated } \\
\text { Performance } \\
\text { Measurement } \\
\text { System }\end{array}$ & $\begin{array}{c}\text { Performance } \\
\text { Prism }\end{array}$ & $\begin{array}{c}\text { Organizational } \\
\text { Performance } \\
\text { Measurement } \\
\text { (OPM) }\end{array}$ & $\begin{array}{c}\text { Integrated } \\
\text { Performance } \\
\text { Measurement for } \\
\text { Small Firms }\end{array}$ \\
\hline Strategic Alignment & 0 & 0 & 0 & \\
\hline Strategy Development & $\bullet$ & $\bullet$ & $\bullet$ & \\
\hline Focus on Stakehoders & $\bullet$ & $\bullet$ & $\bullet$ & \\
\hline Financial and Non Financial Measures & $\bullet$ & $\bullet$ & $\bullet$ & $\bullet$ \\
\hline Dynamic adaptability & $\bullet$ & $\bullet$ & $\bullet$ & $\bullet$ \\
\hline Process Oriented & $\bullet$ & $\bullet$ & $\bullet$ & 0 \\
\hline Depth / Detailing & $\bullet$ & $\bullet$ & $\bullet$ & $\bullet$ \\
\hline Coverage & 0 & $\bullet$ & & $\bullet$ \\
\hline Cause and effect relationship & 0 & $\bullet$ & 0 & $\bullet$ \\
\hline Clarity and simplicity & $\bullet$ & $\bullet$ & $\bullet$ \\
\hline
\end{tabular}

- Meet completely

o Meet partialy

Source: Garengo, Biazzo and Bititci (2005) and Bortoluzzi et al. (2010)

In view of the comparisons observed in Tables 3 and 4, it is possible to verify that the Performance Prism is the most complete model, in accordance with the dimensions listed by Garengo, Biazzo and Bititci (2005). No tool fully meets all the elements, the Performance Prism being the most complete (Bortoluzzi et al., 2010).

\subsection{Performance Prism}

Gaiardelli et al. (2007) present the Performance Prism as a performance measurement system that is concerned with the integration of financial and operational measures in performance measurement. These measures would be related to strategic planning and its structuring is part of a balanced multidimensional approach to indicators.

Taticchi et al. (2010), when carrying out a literature review and research agenda on performance measurement, identified that the Performance Prism is a system that establishes a balanced set of measures which tries to incorporate performance indicators that lead to a better understanding of the processes in a structural design project integrated with management.

In the understanding of Nudurupati et al. (2011) the Performance Prism would be framed among the models of performance measurement systems that are concerned with what to measure and how to structure a system. Therefore, the concern would be to try to answer the following question: "how to design a performance measurement system?".

For Kennerley and Neely (2002), the Performance Prism is inserted as a performance measurement system that aims to help organizations to define a series of indicators that reflect their organizational objectives and enable better performance.

In the understanding of Cunha and Corrêa (2013), the models of traditional performance measurement systems focus intensively on the internal aspects of the organization. Therefore, in the early 2000s, new models emerged that seek to meet the interests of stakeholders as central objectives of the organization and, consequently, establish the organizational strategy. It is in this context that the Performance Prism appears. 
According to Neely et al. (2001) and Folan and Browne (2005), the Performance Prism fits as a system of structural performance measurement. This system model consists of five weighted facets: stakeholder satisfaction, strategies, processes, capacity and stakeholder contribution. For Nascimento et al. (2010) the Performance Prism, when addressing these dimensions, aims to measure the performance of the entire organization.

Torrens, Gomes and Filho (2010) reinforce the idea that the Performance Prism goes beyond internal aspects of the organization. The stakeholder approach gives external focus to the organization. Even so, when addressing strategies, processes and capabilities, the system also focuses internally.

Sorooshian et al. (2016) consider the Performance Prism as a conceptual system of second generation performance measurement system. It is a recent system that is based on previous systems such as the Balanced Scorecard. It is a tool that emphasizes stakeholders. The system establishes that stakeholders support the process indicators, organizational strategies and the efficiencies necessary for better measurement. It is clear that stakeholder satisfaction helps to achieve organizational success.

Neely et al. (2001) state that the understanding of stakeholder satisfaction is broader than the Balanced Scorecard vision, which addresses only customers. While mention is made of suppliers, employees, intermediaries and partners, regulators, the local community, pressure groups and others. In addition, it is a mistake to state that the measures are derived based on the organizational strategy. It exists to add value to stakeholders. Therefore, the measures must start from the needs and desires of the interested parties, passing through the strategy. Thus, the organization must focus on business processes and identify specific measures for each process to implement the strategy. Therefore, it is necessary to have the ability to combine people, practices, technologies and infrastructure so that the processes are well executed. Finally, stakeholders must take actions that contribute to the organization in a reciprocal manner. Reame Júnior and Reame (2007) present the necessary steps for the implementation of the Performance Prism. The first step in implementing the system is to understand what each audience interested in the organization needs and how it can contribute. Next, measures are developed for both dimensions satisfaction and contribution of these audiences. Then the stages that lead the organization to serve the public are structured. The steps consist of defining the necessary strategies, processes and capabilities. For each stage, specific measures are established (Reame Júnior \& Reame, 2007).

Frederico and Cavenaghi (2009) understand that the Performance Prism promotes a more comprehensive approach and stimulates visions in a wide angle, managing to operate in the dimensions of the business where a performance measurement system would not operate. Each facet of the Performance Prism represents key issues crucial to success. Likewise, Tangen (2004) states that the Performance Prism has a much more comprehensive view of different stakeholders.

Neely et al. (2001), Salem et al. (2012) and Tangen (2004) list the key issues that are considered by the Performance Prism, related to the five facets of the performance measurement system model for the organization to be successful. 
Table 4

Key facets and issues of the Performance Prism

\begin{tabular}{|l|l|}
\hline \multicolumn{1}{|c|}{ FACETS } & \multicolumn{1}{c|}{ KEY QUESTIONS } \\
\hline $\begin{array}{l}\text { Stakeholders } \\
\text { Satisfaction }\end{array}$ & Who are the main stakeholders and what do they want and need? \\
\hline Estrategy & $\begin{array}{l}\text { What strategies do we need to put in place to satisfy the wants and needs of } \\
\text { stakeholders? }\end{array}$ \\
\hline Processes & What critical processes do we need if we are going to execute these strategies? \\
\hline Capacity & What resources do we need to operate and improve these processes? \\
\hline $\begin{array}{l}\text { Contribution of } \\
\text { Stakeholders }\end{array}$ & $\begin{array}{l}\text { What contributions do we need from our stakeholders if we are to maintain and } \\
\text { develop these capabilities? }\end{array}$ \\
\hline
\end{tabular}

Source: Neely et al. (2001), Salem et al. (2012) and Tangen (2004) adapted.

Youngbantao and Rompho (2015) state that the use of the Performance Prism helps to reduce the problem of excessive resource consumption and allows the user to create a realistic budget plan. In addition, it allows an organization to respond to the needs of stakeholders based on their social responsibility and allows them to focus on the benefits of stakeholders.

Bourne, Franco and Wilkes (2003) point out that organizations focus widely on stakeholders to ensure attention to all facets of performance. In addition, they test their assumptions using their own data in an attempt to find non-intuitive relationships to gain greater insight into how to improve business management. Linked objectives of the success map with process improvement initiatives create sustainability and better performance. Thus, an effective way to manage business sustainability is to develop the process of obtaining the capacity to improve the base of basic resources.

For Striteska and Spickova (2012), the Performance Prism was introduced in 2001 by Neely, Adam and Kennerley as a comprehensive system that seeks to address the key points of any organization, whether for profit or not. Organizations must pay attention to the wishes and needs of all the main stakeholders and the means to add value to each of them. With that, strategies, processes and capacities must be aligned and integrated in order for these values to be delivered to be realized.

Table 5

Strengths and weaknesses of the Performance Prism

\section{STRENGTHS}

It reflects new stakeholders (such as employees, suppliers, alliance partners or intermediaries) that are often overlooked when forming performance measures.

Considers stakeholder contribution to performance.

Ensures that performance measures have a solid foundation.

WEAKNESSES

It offers little about how performance measures will be implemented.

Some measures are not effective in practice.

Lack of logic between the measures, no sufficient link between the results and the drivers.

No consideration is given to existing performance measurement systems that companies can use.

Source: Striteska and Spickova (2012) adapted

It should be noted that there must be reciprocity in the relationship between the organization and the interested parties. Therefore, stakeholders must also contribute to the

Management Control Review, v. 5, n. 2, Jul/Dez, pp. 61-78, 2020. ISSN 2526-1282. 
organization's wants and needs. In the authors' view, the Performance Prism does not fit into a prescriptive model and has strengths and weaknesses.

Salem et al. (2012) still highlight that the Performance Prism pays little attention to the system's design processes. He tends to neglect issues like how performance measures are going to be carried out. Likewise, Tangen (2004) states that although the performance prism extends beyond the "traditional" measured performance it offers little about how the performance measures will be carried out. In addition, the author points out as well as Striteska and Spickova (2012) that the system gives little or no consideration to the existing Performance Measurement Systems that companies can use.

Torrens, Gomes and Filho (2010), on the other hand, observe as an advantage of the model the fact that it emphasizes stakeholders and as a disadvantage the model is complex and little known in America.

\section{METHODOLOGY}

In order to analyze the perception of public managers about Performance Prism, a questionnaire was applied to the Secretariat of Planning, Budget and Management of the Petrolina City Hall and the Secretariat of Planning and Management of the State Government. This selection was based on accessibility.

Respondents are civil servants who exercise their functions in areas responsible for implementing strategic planning and monitoring the results of government actions.

Thus, this research is characterized as quantitative in terms of its approach. This is due to the use of structured procedures and formal instruments for data collection, under conditions of control and objectivity, having the researcher's point of view external to the studied location (Gerhardt \& Silveira, 2009).

The study can also be considered descriptive because it studies the characteristics of a group and the relationship of variables (Gil, 1989). This understanding is shared by Prodanov and Freitas (2013) who affirm that in a descriptive study the researcher only records and describes the facts observed without interfering with them and it aims to describe the characteristics of a given population or phenomenon or the establishment of relationships between variables (Prodanov \& Freitas, 2013, p. 52).

The questionnaire was divided into three blocks. The first part seeks to identify the characteristics of the respondents through multiple choice responses. The second part deals with the respondents' perception of the level of knowledge of the following performance measurement systems, mentioned in the literature review, using Likert scale. This knowledge scale can be measured from 1 to 5, from the level of least knowledge to the most knowledge. Follow the referenced systems:

- Performance Measurement Matrix;

- Performance Pyramid System (Performance Pyramid System);

- Performance Measurement System for Service Industries (Perfomance Measurement System for Service Industries);

- Balanced Scorecard (BSC);

- Integrated Performance Measurement System;

- Performance Prism;

- Measurement of Organizational Performance (Organizational Performance Measurement);

- Integrated Performance Measurement for Small Firms. 
Still in the second part, the Likert scale (totally unimportant, unimportant, indifferent, important and very important) is measured, the degree of importance given to proposals related to the dimensions of the performance measurement systems, related by Garengo, Biazzo and Bititci (2005) and Bortoluzzi et al. (2010), shown in table 2 of the literature review. The importance scale can be measured from 1 to 5 , from the least important to the most important level.

The last block lists Performance Prism features. In this part, propositions about the performance measurement system were elaborated so that the respondent, also through the Likert scale, established the level of agreement, which would be: totally disagree, disagree, indifferent, agree and totally agree. This agreement scale can be measured from 1 to 5, from the level of least agreement to the level of greatest agreement.

For Vieira and Dalmoro (2008) the Likert scale became popular due to the use of the type of psychometry used in the investigation. It reduces the difficulty of generalizations through the use of a large number of marking options and the complex nature of alternative scales.

The questionnaire was prepared using the Google Forms tool and sent to respondents via e-mail and whatsapp. The response period was from 12/13/2017 to $01 / 02 / 2018$, obtaining two responses from the Secretariat of Planning, Budget and Management of the Petrolina City Hall and fourteen responses from the Secretariat of Planning and Management of the Government of the State of Pernambuco, totaling sixteen responses obtained.

Data analysis was performed using Excel and the STATISTICA statistical system. Based on this system, non-parametric tests were performed using the Kruskal-Wallis model. It was chosen because it makes it possible to compare two or more variables from independent groups.

According to Dunn (1964), if the statistic is not significant, obtaining a p-value $>0.05$, then there is no evidence of stochastic dominance between variables. However, if the test is significant, obtaining a p-value of 0.05 , then at least one variable stochastically dominates the other.

\section{RESULTS}

\subsection{Characteristic of respondents}

As can be seen in table 7 , in addition to the identification of the entity in which the respondents work, data was collected on gender, age, level of education, length of service in the public sector and whether the server has a commissioned position. 
Table 6

Characteristic of respondents

\begin{tabular}{|c|c|c|c|}
\hline Variables & Characteristic & Frequency & Percentage \\
\hline \multirow{3}{*}{ Gender } & Female & 10 & $63 \%$ \\
\hline & Male & 6 & $38 \%$ \\
\hline & TOTAL & 16 & $100 \%$ \\
\hline \multirow{6}{*}{ Age (years) } & From 18 to 25 & 0 & $0 \%$ \\
\hline & From 26 to 33 & 5 & $31 \%$ \\
\hline & From 34 to 41 & 9 & $56 \%$ \\
\hline & From 42 to 49 & 2 & $13 \%$ \\
\hline & More than 49 & 0 & $0 \%$ \\
\hline & TOTAL & 16 & $100 \%$ \\
\hline \multirow{4}{*}{$\begin{array}{l}\text { Level of } \\
\text { education }\end{array}$} & Secondary & 0 & $0 \%$ \\
\hline & Graduate & 0 & $0 \%$ \\
\hline & Post Graduate & 16 & $100 \%$ \\
\hline & TOTAL & 16 & $100 \%$ \\
\hline \multirow{6}{*}{$\begin{array}{l}\text { Lenght in public } \\
\text { service (years) }\end{array}$} & Less than 5 & 2 & $13 \%$ \\
\hline & From 5 to 15 & 13 & $81 \%$ \\
\hline & From 16 to 26 & 0 & $0 \%$ \\
\hline & From 27 to 37 & 1 & $6 \%$ \\
\hline & More than 37 & 0 & $0 \%$ \\
\hline & TOTAL & 16 & $100 \%$ \\
\hline \multirow{3}{*}{$\begin{array}{l}\text { Comission } \\
\text { position }\end{array}$} & Yes & 7 & $44 \%$ \\
\hline & No & 9 & $56 \%$ \\
\hline & TOTAL & 16 & $100 \%$ \\
\hline
\end{tabular}

Source: Research.

There is a predominance of female participation, representing a relative frequency of $63 \%$. As for age, it is observed that $87 \%$ of those surveyed are in the range of 26 to 41 years of age, with the majority concentrated between 34 and 41 years of age.

Regarding schooling, it appears that all respondents have graduate degrees. Therefore, it is understood that the respondents who work with the implementation of strategic planning and monitoring of results are well qualified.

With regard to public service time, $81 \%$ of respondents predominated between 5 and 15 years of experience. In addition, $44 \%$ of those surveyed have commissioned positions. In other words, of the respondents, almost half work in terms of direction and advice.

\subsection{Perception about Performance Measurement Systems}

Based on the work done by Garengo, Biazzo and Bititci (2005) and Bortoluzzi et al. (2010), an analysis was made of the respondents' perception of performance measurement systems.

So, first, questioning about the degree of knowledge about a list of systems was carried out. As can be seen in Table 8, on a scale of 1 to 5, an average level of knowledge below 2 . The respondents have a low level of knowledge about the systems surveyed. Only the Balanced Scorecard (BSC) had an average knowledge level above 3, which refers to a good level of knowledge.

Regarding the Performance Prism, the level of knowledge was low, obtaining an average of 1.1875. The respondents are unaware of this performance measurement system. 
Table 7

Degree of knowledge about performance measurement systems

\begin{tabular}{|c|c|c|c|c|c|c|}
\hline \multirow{2}{*}{$\begin{array}{c}\text { Performance } \\
\text { Measurement System }\end{array}$} & \multirow{2}{*}{$\begin{array}{l}\text { Degree } \\
\text { (Mean) }\end{array}$} & \multirow{2}{*}{$\begin{array}{l}\text { Degree } \\
\text { (Std. Dev) }\end{array}$} & \multicolumn{4}{|c|}{$\begin{array}{c}\begin{array}{c}\text { Kruskal-Wallis test: } \mathrm{H} \\
(p-v a l u e)\end{array} \\
\end{array}$} \\
\hline & & & GENDER & AGE & LENGHT & COMISSION \\
\hline $\begin{array}{l}\text { Performance } \\
\text { Measurement Matrix }\end{array}$ & 1.312 & 0.6818 & 0.9365 & 0.2788 & 0.5999 & 0.4368 \\
\hline $\begin{array}{l}\text { Performance Pyramid } \\
\text { System }\end{array}$ & 1.3750 & 0.6960 & 0.4751 & 0.7858 & 0.5180 & 0.5771 \\
\hline $\begin{array}{l}\text { Performance } \\
\text { Measurement System } \\
\text { for Service Industries) }\end{array}$ & 1.1875 & 0.5266 & 0.7773 & 0.2609 & 0.1959 & 0.7825 \\
\hline Balanced Scorecard & 3.5000 & 1.0607 & 0.3969 & 0.3489 & 0.3396 & 0,8687 \\
\hline $\begin{array}{l}\text { Integrated } \\
\text { Performance } \\
\text { Measurement System }\end{array}$ & 1,4375 & 0.7881 & 0.4309 & 0.8678 & 0.5702 & 0.6750 \\
\hline Performance Prism & 1.1875 & 0.5266 & 0.7773 & 0.2609 & 0.1959 & 0.7825 \\
\hline $\begin{array}{l}\text { Organizational } \\
\text { Performance } \\
\text { Measurement }\end{array}$ & 1.6250 & 1.0533 & 0.8949 & 0.6712 & 0.4517 & 0.6988 \\
\hline $\begin{array}{l}\text { Integrated } \\
\text { Performance } \\
\text { Measurement } \\
\text { Small Firms }\end{array}$ & 1.1875 & 0.5266 & 0.7773 & 0.2609 & 0.1959 & 0.7825 \\
\hline
\end{tabular}

Source: Research.

When performing the Kruskal-Wallis $\mathrm{H}$ test with the block of variables of knowledge of the performance measurement systems with the block of variables that characterize the respondents, levels of significance were not identified. That is, the p-values obtained in the test were all greater than 0.05 - as can be seen in table 8 .

Also based on the work done by Garengo, Biazzo and Bititci (2005) and Bortoluzzi et al. (2010), questions were asked about the degree of importance of the dimensions of performance measurement systems. It can be seen from Table 9, that on a scale of 1 to 5, the average level of importance in general was higher than 4 . Therefore, the dimensions listed were perceived as important and very important, with clarity and simplicity as the most important (average of 4.9375) and coverage as the least important (average of 3.8750). It is worth mentioning that the focus on stakeholders obtained an average importance of 4.3750 . 
Table 8

Degree of importance of the dimensions of performance measurement systems

\begin{tabular}{|l|c|c|c|c|c|c|c|}
\hline \multirow{2}{*}{\begin{tabular}{c}
\multirow{2}{*}{$\begin{array}{c}\text { Dimensions of } \\
\text { performance } \\
\text { measurement systems }\end{array}$} \\
Degree
\end{tabular}} & \multirow{2}{*}{$\begin{array}{c}\text { Degree } \\
\text { (Mean) }\end{array}$} & & \multicolumn{5}{c|}{$\begin{array}{c}\text { Kruskal-Wallis test: H } \\
\text { (Std. Devalue })\end{array}$} \\
\cline { 5 - 9 } & & & GENDER & AGE & LENGHT & COMISSION & PRISM \\
\hline Strategic Alignment & 4.5625 & 0.4961 & 0.1658 & 0.6361 & 0.2602 & 0.2960 & 0.3793 \\
\hline Strategy Development & 4.5000 & 0.5000 & 0.3173 & 0.1599 & 0.6036 & 0.1432 & 0.3425 \\
\hline Focus on Stakehoders & 4.3750 & 0.5995 & 0.3613 & 0.9625 & 0.7512 & 0.8586 & 0.5647 \\
\hline $\begin{array}{l}\text { Financial and Non } \\
\text { Financial Measures }\end{array}$ & 4.5000 & 0.5000 & 1.0000 & 0.3385 & 0.6036 & 0.6256 & 0.3916 \\
\hline Dynamic adaptability & 4.5625 & 0.6092 & 0.1819 & 0.0501 & 00711 & 0.8524 & 0.4102 \\
\hline Process Oriented & 4.1250 & 0.9270 & 0.5637 & 0.7549 & 0.3228 & 0.7782 & 0.4066 \\
\hline Depth / Detailing & 3.9375 & 1.1973 & 0.2207 & 0.7248 & 0.2547 & 0.3625 & 0.8770 \\
\hline Coverage & 3.8750 & 1.3170 & 0.9081 & 0.9857 & 0.1884 & 0.6121 & 0.4066 \\
\hline $\begin{array}{l}\text { Cause and effect } \\
\text { relationship }\end{array}$ & 4.6875 & 0.4635 & 0.2249 & 0.6724 & 0.6927 & 0.8435 & 0.2819 \\
\hline Clarity and simplicity & 4.9375 & 0.2421 & 0.4386 & 0.3329 & 0.8910 & 0.3778 & 0.9311 \\
\hline
\end{tabular}

Source: Research

The Kruskal-Wallis $\mathrm{H}$ test with the block of variables of importance of the dimensions of performance measurement systems with the block of variables that characterize the respondents, did not demonstrate levels of significance. That is, the p-values obtained in the test were all greater than 0.05 - as can be seen in table 9 .

In this test, the knowledge variable about the performance prism was also included to verify any significance. As can also be seen in Table 9, the p-values obtained in the test were all greater than 0.05 .

\subsection{Perception about Performance Prim}

Through what the authors said about the Performance Prism system, propositions were listed for respondents to indicate the degree of agreement on the statements. It is noteworthy that the proposition "Seeking to meet the wishes of interested parties causes the organization to lose focus for better performance" was inserted by this author to seek the perception of respondents as to the possibility of losing the best results when trying to reconcile the fulfillment of the wishes of several interested parties. 
Table 9

Degree of agreement on proposals on the Performance Prism

\begin{tabular}{|c|c|c|c|c|c|c|c|}
\hline \multirow{2}{*}{ Proposition } & \multirow{2}{*}{$\begin{array}{l}\text { Degree } \\
\text { (Mean) }\end{array}$} & \multirow{2}{*}{$\begin{array}{c}\text { Degree } \\
\text { (Std. Dev.) }\end{array}$} & \multicolumn{5}{|c|}{$\begin{array}{c}\text { Kruskal-Wallis test: } \mathrm{H} \\
(p-v a l u e)\end{array}$} \\
\hline & & & GENDER & AGE & LENGHT & COMISSION & PRISM \\
\hline $\begin{array}{l}\text { Understanding } \\
\text { satisfaction } \\
\text { stakeholders to the } \\
\text { organization } \\
\text { broader than the } \\
\text { vision of a system } \\
\text { that addresses only } \\
\text { citizen satisfaction }\end{array}$ & 3.8750 & 1.2183 & 0.9541 & 0.8667 & 0.4597 & 0.7362 & 0.3658 \\
\hline $\begin{array}{l}\text { Focusing } \\
\text { stakeholders is more } \\
\text { appropriate for a } \\
\text { performance } \\
\text { measurement system } \\
\text { applied in the public } \\
\text { sector }\end{array}$ & 3.8125 & 1.1842 & 0.2311 & 0.1327 & 0.3584 & 0.6969 & 0.3838 \\
\hline $\begin{array}{l}\text { Strategies, processes } \\
\text { and capabilities must } \\
\text { be aligned and } \\
\text { integrated in order } \\
\text { for the organization } \\
\text { to achieve better } \\
\text { performance }\end{array}$ & 4.7500 & 0,4330 & 0,5637 & 0.5427 & 0.5616 & 0.3980 & 0.6997 \\
\hline $\begin{array}{l}\text { Performance } \\
\text { measures should } \\
\text { have } \\
\text { multidimensional a } \\
\text { balanced structure }\end{array}$ & 4.3750 & 0.7806 & 0.5860 & 0.1479 & 0.6881 & 0.3153 & 0.2049 \\
\hline $\begin{array}{l}\text { Seeking to meet the } \\
\text { wishes of } \\
\text { stakeholders makes } \\
\text { the organization lose } \\
\text { focus for better } \\
\text { performance }\end{array}$ & 2.7500 & 1.3463 & $0.0371^{*}$ & 0.6044 & 0.0788 & 0.1237 & 0.2472 \\
\hline $\begin{array}{l}\text { Identify who the } \\
\text { main stakeholders are } \\
\text { and what they want } \\
\text { and need }\end{array}$ & 4.6875 & 0.4635 & 0.3452 & 0.6724 & 0.4553 & 0.8435 & 0.2819 \\
\hline $\begin{array}{l}\text { We must analyze } \\
\text { what } \\
\text { processes we need, if } \\
\text { we are going to } \\
\text { execute the strategies }\end{array}$ & 4.5000 & 0.6124 & 0.7576 & 0.0552 & 0.6884 & 0.2524 & 0.0969 \\
\hline $\begin{array}{l}\text { It should be checked } \\
\text { which strategies we } \\
\text { have to put in place } \\
\text { to satisfy the wishes } \\
\text { and needs of the } \\
\text { interested parties }\end{array}$ & 4.4375 & 0.8638 & 0.8503 & 0.8118 & 0.3727 & 0.6673 & 0.2126 \\
\hline $\begin{array}{l}\text { List what resources } \\
\text { we need to operate } \\
\text { and } \\
\text { processes }\end{array}$ & 4.5625 & 0.6 .092 & 0.7029 & 0.9592 & 0.7319 & 0.7097 & 0.2460 \\
\hline $\begin{array}{l}\text { We must understand } \\
\text { what contributions } \\
\text { we need from our } \\
\text { stakeholders if we are } \\
\text { to maintain and } \\
\text { develop } \\
\text { capabilities }\end{array}$ & 4.5625 & 0.6092 & 1.0000 & 0.9592 & 0.7319 & 0.4566 & 0.2460 \\
\hline
\end{tabular}

Source: Research

Note: $(*)$ relações estatisticaly significat $(p$-value $\leq 0,05)$. 
The Kruskal-Wallis $\mathrm{H}$ test with the block of concordance variables for the propositions on the Performance Prism with the block of variables that characterize the respondents showed a level of significance only for the proposition "Seeking to meet the wishes of the interested parties makes the organization loses focus for better performance "with the gender variable. Although, as has been seen, for this proposition there was a low level of agreement, the female gender had a higher degree of disagreement, while the male gender had a higher degree of agreement, as shown in table 11.

Table 10

Frequency distribution of proposition agreement and gender

\begin{tabular}{|l|r|r|r|r|r|r|}
\hline \multirow{2}{*}{ Gender } & \multicolumn{2}{c|}{ Female } & \multicolumn{2}{c|}{ Male } & \multicolumn{2}{c|}{ Total } \\
\cline { 2 - 7 } & frequency & percentage & frequency & percentage & frequency & percentage \\
\hline Strongly disagree & 3 & $30 \%$ & 0 & $0 \%$ & 3 & $19 \%$ \\
\hline Disagree & 5 & $50 \%$ & 1 & $17 \%$ & 6 & $38 \%$ \\
\hline Neutral & 0 & $0 \%$ & 1 & $17 \%$ & 1 & $6 \%$ \\
\hline Agree & 1 & $10 \%$ & 3 & $50 \%$ & 4 & $25 \%$ \\
\hline Strongly agree & 1 & $10 \%$ & 1 & $17 \%$ & 2 & $13 \%$ \\
\hline Total & 10 & $100 \%$ & 6 & $100 \%$ & 16 & $100 \%$ \\
\hline
\end{tabular}

Source: Research

In this test, the knowledge variable about the performance prism was also included to verify any significance. As can also be seen in Table 10, the p-values obtained in the test were all greater than 0.05 .

\section{FINAL CONSIDERATIONS}

This research aimed to analyze the perception of public managers who work in the implementation of strategic planning and performance measurement on performance measurement systems, with an emphasis on the Performance Prism.

Thus, conceptual aspects about performance measurement systems were addressed, going through the presentation of descriptions of eight systems models, considered as main models in the view of Garengo, Biazzo and Bititci (2005) and the dimensions that the systems models must have. It was also presented what the literature discusses about the Performance Prism.

It was seen that the Performance Prism is a system that aims to measure the performance of the entire organization. For this reason, it is considered to be structural based on five facets that can be represented through a prism figure: stakeholder satisfaction, strategies, processes, capabilities and stakeholder contribution. Thus, it can be said that it is based on the focus on stakeholders to obtain the best performance.

Then, based on the literature, an electronic questionnaire was developed to capture data on the perception of public servants who work with the implementation of strategic planning and monitoring of results in the Planning, Budget and Management Secretariat of the Petrolina City Hall and the Planning Secretariat and Management of the Government of the State of Pernambuco. 
It was found that the respondents do not have extensive knowledge about the performance measurement systems listed in the survey, except for the Balanced Scorecard (BSC) and the system with the lowest level of knowledge was the Performance Prism. This lack of knowledge about the Performance Prism is consistent with the perception of Frederico and Cavenaghi (2009) and Salem et al. (2012).

Regarding the dimensions of the performance measurement system, a high average degree of importance was observed for all dimensions, which includes focus on stakeholders.

Proposals on aspects of the Performance Prism were presented to the respondents to verify the degree of agreement. It was found that although there was no knowledge about the performance measurement system, there was, in general, a high degree of agreement on the propositions. The only proposition that had a low level of agreement was "Seeking to meet the wishes of interested parties causes the organization to lose focus for better performance" In this same proposition, significance was identified, using the Kruskal-Wallis $\mathrm{H}$ test, significance regarding the sex. Men agreed with the proposition and women disagreed.

The characteristic of the Performance Prism in being focused on interested parties was perceived as important by the respondents, even though there was no knowledge about the performance measurement system. As it is a structural system that can be applied to nonprofit organizations, as understood by Striteska and Spickova (2012), its implementation in the public sector can bring benefits to the performance of public administration.

Then, finally, as a limiter of the research, one can identify the quantity of responses obtained by two public entities and the use of only one statistical test to measure the significance of the relationship between groups of independent variables. Therefore, it is suggested for future research to use other statistical tests and to obtain more answers from other public entities.

\section{REFERENCES}

Ahmad, S., Svalestuena, F., Andersena, B. \& Torpa, O. (2016). A review of performance measurement for successful concurrent construction. Procedia - Social and Behavioral Sciences, 226, 447-454.

Angerhofer, B. \& Angelides, M. (2006). A model and a performance measurement system for collaborative supply chains. Decision Support Systems 42, 283-301.

Bititci, U. S., Carrie, A. S. \& McDevitt, L. (1997). Integrated performance measurement systems: a development guide. International Journal of Operations \& Production Management, 17(5), 522-534.

Bortoluzzi, S., Ensslin, S.R., Ensslin, R., Vicente, E.F.R. (2010). Práticas de avaliação de desempenho organizacional em pequenas e médias empresas: investigação em uma empresa de porte médio do ramo moveleiro. Revista Produção Online, 10(3), 551-576.

Bourne, M., Mills, J., Wilcox, M., Neely, A. \& Platts, K. (2000). Designing, implementing and updating performance measurement systems. International Journal of Operations \& Production Management, 20(7), 754-771.

Bourne, M., Franco, M. \& Wilkes, J. (2003). Corporate performance management. Measuring Business Excellence, 7(3), 15-21.

Brewer, P. \& Speh, T. (2000). Using the balanced scorecard to measure suplly chain performance. Journal of Business Logistics, 21(1), 75-93. 
Callado, A.A.C. \& Oliveira, R.R. (2016). Análise da intensidade de adoção de indicadores de desempenho: uma abordagem contextual a partir de uma perspectiva institucional. Revista Contabilidade e Organizações, 10(26), 20-32.

Callado, A. A. C. \& Callado, F. M. R. de A. (2018). Análise do processo de construção de indicadores de desempenho operacional: estudo de caso em um hospital público de hematologia. RAHIS, 15(2), 1-12.

Cunha, J. \& Corrêa, H. (2013). Avaliação de desempenho organizacional: um estudo aplicado em hospitais filantrópicos. $R A E, 53(5), 485-499$.

Dunn, O. (1964). Multiple comparisons using rank sums. Technometrics, 6(3), 241-252.

Ferreira, G. R. \& Callado, A. A. C. (2017). Relações entre o perfil do calculista, características dos processos e a eficácia das contestações: Um estudo na divisão de cálculos da procuradoria geral do estado de Pernambuco. Revista Capital Científicoeletrônica, 15(4),111-128.

Folan, P. \& Browne, J. (2005). A review of performance measurement: Towards performance management. Computers in Industry, 56, 663-680.

Frederico, G. \& Cavenaghi, V. (2009). The measurement of organizational performance with a focus on stakeholders: a performance prism approach. Proceedings. POMS 20th Annual Conference Orlando.

Gaiardelli, P., Saccani, N., Songini, L. (2007). Performance measurement of the after-sales service network - Evidence from the automotive industry. Computers in Industry, 58(7), $698-708$.

Garengo, P., Biazzo, S. \& Bititci, U. S. (2005). Performance measurement systems in SMEs: A review for a research agenda. International Journal of Management Reviews, 7(1), 2547.

Gerhardt, T. \& Silveira, D. (2009). Métodos de Pesquisa. Universidade Federal do Rio Grande do Sul. Rio Grande do Sul.

Gil, A. C. (1989). Métodos e Técnicas de Pesquisa Social. 2ed, São Paulo, Atlas.

Klann, R. \& Beuren, I. (2014). Relação do empowerment psicológico com o sistema de mensuração de desempenho e desempenho gerencial. Revista Ambiente Contábil, 6(2), $116-133$.

Lardenoije, E., Van Raaij, E. M. \& Van Weele, A. J. et al. (2005). Performance Management Models and Purchasing: Relevance Still Lost. Researches in Purchasing and Supply Management. Proceedings. the 14th IPSERA Conference, 687-697.

Leite, L. R., Araujo, J. B. de \& Martins, R.A. (2011). Sustentabilidade como direcionador de evolução dos sistemas de medição de desempenho. Navus - Revista de Gestão e Tecnologia, 1(1), 35-50.

Melnyk, S. A., Stewart, D. M. \& Swink, M. (2004). Metrics and performance measurement in operations management: dealing with the metrics maze. Journal of Operations Management, 22(3), 209-217.

Nascimento, S. do, Bortoluzzi, S. C., Coelho, A. L. L., Coelho, C \& Ensslin, S. R. (2000). Ferramentas gerenciais à luz do desempenho organizacional. Pretexto, 11(3), 34-57. 
Neely, A., Gregory, M. \& Platts, K. (1995). Performance measurement system design: A literature review and research agenda. International Journal of Operations \& Production Management, 15(4), 80-116.

Neely, A., Adams, C. \& Crowe, P. (2001). The Performance Prism in Pratice. Measuring Business Excellence, 5(2), 6-13.

Neely, A. (2005). The evolution of performance measurement research: developments in the last decade and a research agenda for the next. International Journal of Operations \& Production Management, 25(12), 1264-1277.

Kennerley, M. \& Neely, A. (2002). A framework of the factors affecting the evolution o performance measurement systems. International Journal of Operations \& Production Management, 22(11), 1222-1245.

Nudurupati, S., Bititci, U. S., Kumar, V. \& Chan, F. T. S. (2011). State of the art literature review on performance measurement. Computers \& Industrial Engineering, 60(2), 279290.

Prodanov, C. \& Freitas, E. (2013). Metodologia do Trabalho Científico: Métodos e Técnicas da Pesquisa e do Trabalho Acadêmico. Universidade Feevale, $2^{\mathrm{a}}$ ed., Novo Hamburgo.

Reame Junior, E. \& Reame, G. (2007). A Aplicabilidade do Balanced Scorecard e do Performance Prism como Modelos de Sistemas de Medição de Desempenho Organizacional. Interface Tecnológica, 4(1), $76-88$.

Salem, M. A., Hasnan, N., Nor, H. \& Osman, N. H. (2012). Balanced scorecard: weaknesses, streigths, and its ability as performance management system versus other performance management systems. Journal of Environment and Earth Science, 2(9), 76-656.

Sorooshian, S., Aziz, N. F., Ahmad, A., Jubidin, S. N. \& Mustapha, N. M. (2016). Review on Performance Measurement Systems. Mediterranean Journal of Social Sciences, MCSER Publishing, 7(1), 68-87.

Striteska, M. \& Spickova, M. (2012). Review and Comparison of Performance Measurement Systems. Journal of Organizational Management Studies, 1-12.

Taticchi, P., Tonelli, F. \& Cagnazzo, L. (2010). Performance measurement and management: a literature review and a research agenda. Measuring Business Excellence, 14(1), 4-18.

Tangen, S. (2004). Performance measurement: from philosophy to practice. International Journal of Productivity and Performance Management, 53(8), 726-737.

Torrens, E.,Gomes, G. \& Filho, J. (2010). Estudo comparativo entre as teorias de avaliação de desempenho das empresas. Anais. XVII Congresso Brasileiro de Custos.

Vieira, M. \& Dalmoro, M. (2008). Dilemas na Construção de Escalas Tipo Likert: o Número de Itens e a Disposição Influenciam nos Resultados? Anais. XXXII Encontro da ANPAD.

Youngbantao, U. \& Rompho, N. (2015). The Uses of Measures in Performance Prism in Different Organizational Cultures. Journal of Accounting and Finance, 15(6), 122-128. 